\section{Gardeners' Perceptions of Northwestern U.S. Native Plants Are Influenced by Ecological Information and Garden Group Affiliation}

\author{
Aaron G. Anderson ${ }^{1}$, Isabella Messer ${ }^{1}$, and Gail A. Langellotto ${ }^{1}$
}

ADDITIONAL INDEX WORDS. gardener preferences, native plant gardening, pollinator plants, urban habitat

\begin{abstract}
SuMMARY. Plantings of native flowers are often installed to increase the pollinator habitat in urban and suburban gardens. However, in many regions, it is not known which native plants are best used for pollinator plantings in gardens. Candidate plants must be attractive to pollinators, but they also must have attributes that gardeners find appealing. To identify native plants that are attractive to gardeners, we disseminated two surveys. The first asked gardeners to use a 5-point Likert scale to rate how likely they would be to garden with 23 flowering plants native to the Pacific Northwest United States. The second survey asked gardeners to use a 5-point Likert scale to rate how likely they would be to garden with a subset of 11 of these 23 native plants before and after receiving information about each flower's attractiveness to bees (Anthophila). Using the first survey, we found a high level of acceptance of native plants by home gardeners (6 of 23 flowers had a mean "likelihood of planting" score of $\geq 4$ ). Additionally, gardeners stated their likelihood of planting these native species increased significantly after receiving information about the bees associated with each plant. Across both surveys, gardeners who identified as "native plant gardeners" stated they would be significantly more likely to garden with all native plant species. Both surveys included an opportunity to share openended comments, which revealed that gardeners were most concerned with flower aesthetics and the aggressiveness of growth. Gardeners felt most positively about flower aesthetics and beneficial ecological traits. Many gardeners also commented that they needed more information or were unfamiliar with the plants. This study shows that native plants can have high baseline appeal to home gardeners. Specifically, we identified five native plant species that northwestern U.S. nurseries might consider growing and marketing as pollinator plants because of their high level of attractiveness to bees and home gardeners: globe gilia (Gilia capitata), california poppy (Eschscholzia californica), douglas aster

(Symphyotrichum subspicatum), oregon sunshine (Eriophyllum lanatum), and common yarrow (Achillea millefolium).
\end{abstract}

I nterest in ecological gardening has increased in recent years, largely driven by concerns over environmental issues, including water use and the potential invasiveness of ornamental garden species (Kauth and Pérez, 2011). A common theme of ecological gardening efforts is the inclusion of native plants in landscape design (Uren et al., 2015). Research suggests

Received for publication 7 Dec. 2020. Accepted for publication 16 Apr. 2021.

Published online 2 June 2021.

${ }^{1}$ Department of Horticulture, Oregon State Univer sity, 4017 Agriculture and Life Sciences Building, Corvallis, OR 97331

A.G.A. is the corresponding author. E-mail: andeaaro@oregonstate.edu.

This is an open access article distributed under the CC BY-NC-ND license (https://creativecommons. org/licenses/by-nc-nd/4.0/).

https://doi.org/10.21273/HORTTECH04770-20 that gardens composed of native plants are associated with higher native insect versity between sites in a community) than those planted with exotic species (Burghardt and Tallamy, 2015). Other studies have shown that exotic plant species support lesser insect species abundance than native plants (Burghardt et al., 2010). Further work by Narango et al. (2017) suggested that urban plantings should include native plant species to provide improved habitats and sustain native fauna.

When considering bees (Anthophila) in particular, many species are generalists and can be found broadly foraging across an array of native, nonnative, and cultivated plant species (Baldock et al., 2015; Matteson and Langellotto, 2011; Salisbury et al., 2015; $\beta$-diversity (the change in species di-
Williams et al., 2011). Nonetheless, gardens with higher proportions of native plants may experience increased bee activity (Fukase and Simons, 2016) and those with more diverse native plant groups increased pollinator diversity (Hostetler and McIntyre, 2001). Therefore, the use of native plant species in garden habitats may help conserve broad insect groups in urban and suburban landscapes, which is particularly timely because of recent reports of global declines in insect populations (Hallmann et al., 2017; Sánchez-Bayo and Wyckhuys, 2019).

Because of their ecological benefits, native plants are a market niche that nursery plant growers and vendors could target. Currently, native plant gardening is an area of interest and growth in the landscaping and nursery industries. The American Society of Landscape Architects ranked native plants and drought-tolerant plants as the two most popular landscape and garden trends in 2018 (Howard, 2018), and the use of native plants by landscape architects and contractors in the southeastern United States has increased with clientele interest (Brzuszek and Harkess, 2009). Despite increasing public interest in incorporating native plants in gardens and other ornamental landscapes, these species are not widely planted by home gardeners and are not widely available at retail nurseries (Avolio et al., 2018; Loram et al., 2008 ). It is unclear how public interest is balanced with the barriers to adoption that exist at the consumer level and the production level.

On the consumer level, a lack of availability contributes heavily to the low rate of adoption of native garden plants (Wilde et al., 2015). Native plants of limited diversity are available for sale at nurseries, and $74 \%$ of the vascular plant species native to the United States are not sold commercially (White et al., 2018). Additionally, gardeners tend to lack knowledge about native plants (Kauth and Pérez, 2011), thereby compounding the issue of availability because gardeners who are not aware of native plants will not request them to be stocked for sale. Finally, consumers tend to prefer cultivated plants that have been bred for aesthetic appeal, or garden standards that are familiar and traditionally used in ornamental landscapes (Yue et al., 2012). 
Multiple barriers to adoption also exist at the production level. Nurseries will not increase their selection of native plants for sale unless a market exists for these species, forming a feedback loop with a lack of demand from consumers (Wilde et al., 2015). From a production standpoint, there is limited information regarding the performance of native plants across a realistic range of garden settings, thus complicating the prioritization of plants to produce for sale. Similarly, propagation methods for these plants are generally lacking, and smaller niche nurseries lack resources to create protocols or introduce new plants into production (Norcini, 2007). In addition, the localized nature of native plants means that markets are regionalized. This can make it difficult for growers to scale-up production and can limit sales to smaller geographic regions.

If nursery growers are interested in meeting the public's demand for native plants, then it would be useful to know which plants show the most promise for retail sales and how gardeners who identify as native plant gardeners (compared to the general gardening public) perceive native plants as garden plants. Therefore, we conducted two online surveys to quantify the appeal of flowering plants that are native to the northwestern United States. The objective of our first survey was to quantify the baseline appeal of 23 native northwestern U.S plant species to gardeners. For this first survey, we hypothesized that gardeners who identified themselves as a native plant gardener would find native plants more aesthetically appealing and would be more willing to include these native plants in their gardens than other gardeners.

The objective of the second survey was to investigate whether access to information regarding the ecological benefits of specific native plants would change gardeners' opinions of these plants. We hypothesized that all gardeners would increase their positive impression of native plants by a similar magnitude, irrespective of demographic group, after learning about the bees that are associated with various native plant species. Again, we hypothesized that gardeners who identify as native plant gardeners would rank these plants higher, overall, than non-native plant gardeners.

\section{Materials and methods}

STUdy PLANTS. A total of 23 native plant species (Table 1) were selected for this survey. These plants were chosen based on their drought tolerance, pollinator appeal, and ability to grow in full sun. These filters resulted in a list of 63 potential native plant species, and the final species were selected in cooperation with a landscape designer who used her experience with these plants and her knowledge of past clients' preferences to examine an initially broad list and suggest 23 that had high potential for adoption by home gardeners. She also noted that her past client choices were largely influenced positively by aesthetics and negatively by aggressive growth (S. Danler, personal communication). We used the U.S. Department of Agriculture (USDA) PLANTS online database to confirm the native status of each species (USDA, 2016). These species are also being tested during a field study seeking to quantify their attractiveness to pollinators, natural enemies, and predators.

Survey Development. We assessed the attitudes of gardeners toward 23 native plants using two online surveys created using a web-based survey tool (Qualtrics XM; Qualtrics, Provo, UT). Using the first, or aesthetic preferences, survey (Supplemental Material S1), we sought to ascertain the baseline appeal of native plants using two metrics: perceived aesthetics and the gardeners' willingness to include a

Table 1. List of 23 flowering plants native to the northwestern United States included on two surveys about native plant preferences of gardeners. The native range was determined using the PLANTS database (USDA, 2016).

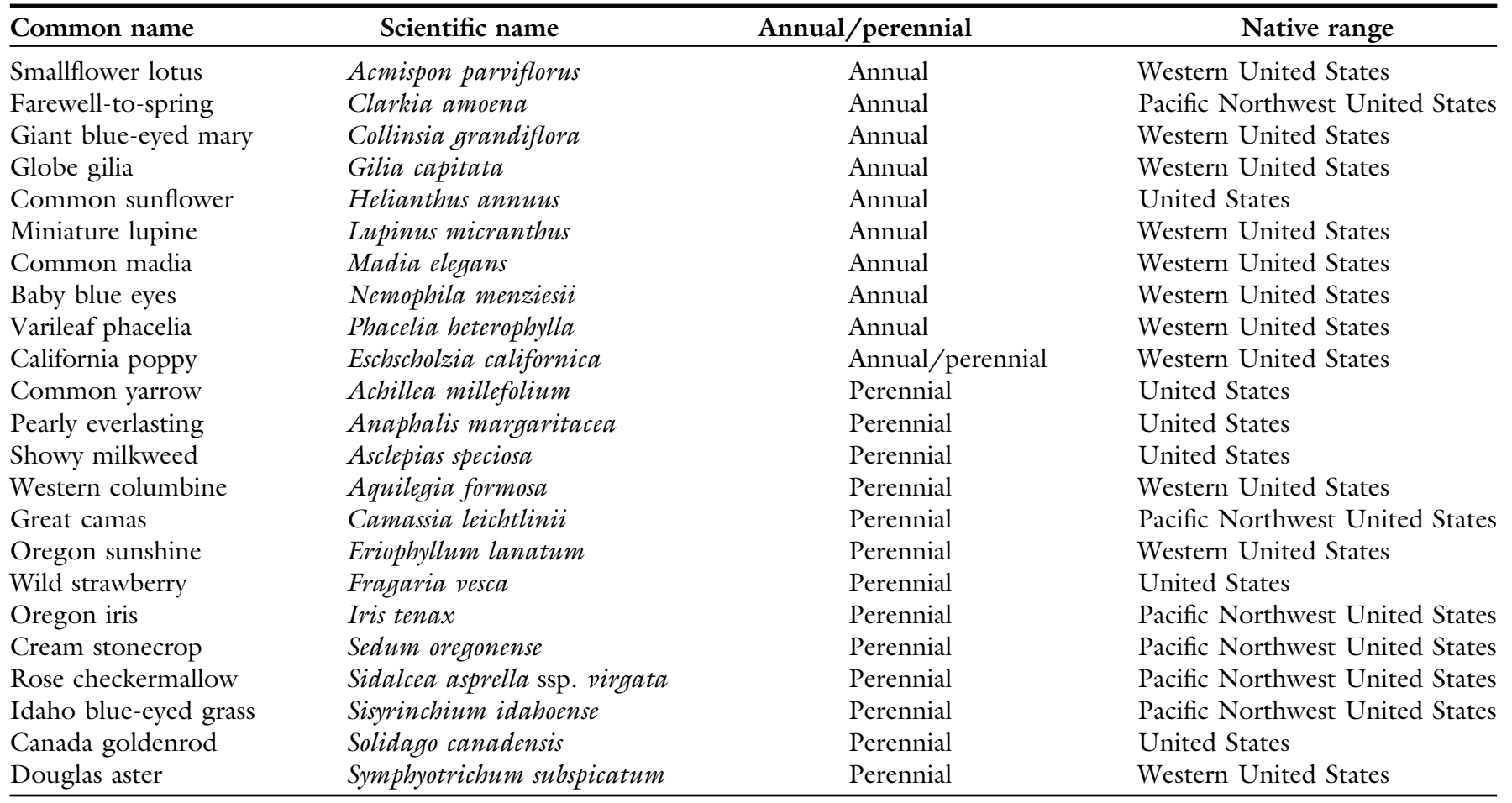


particular plant in their own gardens. Institutional Review Board approval was obtained for these surveys in July 2018.

We displayed photographs of each native plant in bloom. These photographs were either obtained by us in the field or licensed by Creative Commons (Mountain View, CA) and available on the Internet. We included a close-up image of a representative flower and a second, more zoomed-out photograph of the flower with foliage if the first photograph did not capture it. These images were followed by the Likert scale questions "on a scale of $1-5$, how attractive do you find this flower?" and "on a scale of 1-5, how likely would you be to plant this flower in your home garden?", where 1 was the lowest score and 5 was the highest score. Each of these questions also included a text box to allow respondents to make open-ended comments about each species.

The survey also included demographic questions related to how long respondents have been gardening and whether they considered themselves to be native plant gardeners. We also asked respondents to identify barriers that would prevent them and other gardeners from adopting native plants in garden settings (see Supplemental Material S1 for all questions).

The questions in the second, or ecological benefits, survey (Supplemental Material S2) largely mirrored the questions from the aesthetic preferences survey. Specifically, the demographic questions were the same (except for the addition of a question asking about the gardeners' locations). As in the aesthetic preferences survey, we asked gardeners to rate each native plant species for attractiveness and their willingness to include this plant in their gardens using a 5point Likert scale ( $1=$ lowest score; 5 = highest score). However, there were a few key differences between the two surveys. First, instead of asking gardeners about their impressions of the full set of 23 native plants, we instead focused on 11 plants that showed promise as highly attractive pollinator plants based on a broader field experiment we were conducting to assess these plants' attractiveness to insect visitors (A.G. Anderson and G.A. Langellotto, unpublished data). During this experiment, we planted all
23 native plants in individual experimental plots in the field, sampled the pollinator communities visiting them using an insect vacuum, and observed the abundance of pollinator visitors via timed counts. The 11 plants were common yarrow (Achillea millefolium), pearly everlasting (Anaphalis margaritacea), douglas aster (Symphyotrichum subspicatum), farewell-to-spring (Clarkia amoena), oregon sunshine (Eriophyllum lanatum), california poppy (Eschscholzia californica), globe gilia (Gilia capitata), common madia (Madia elegans), varileaf phacelia (Phacelia beterophylla), rose checkermallow ( $\mathrm{Si}$ dalcea asprella ssp. virgata), and canada goldenrod (Solidago canadensis). Second, after gardeners ranked each plant according to their attractiveness and willingness to plant, they were shown information that we had gleaned from 2 years of data collection (A.G. Anderson and G.A. Langellotto, unpublished data) as well as a photograph of a pollinator on that flower. For example, "Phacelia heterophylla attracted the highest abundance and species richness of bumblebee species in 2018" (Supplemental Material S2). After learning about the bees that were associated with each native plant species, gardeners were queried about whether they viewed the plant species more favorably, less favorably, or the same. Finally, gardeners were asked to once again to rate how attractive they found the flowering native plants and how likely they would be to use the species in their gardens using the 5-point Likert scale.

Survey Distribution. Both surveys were distributed via e-mail listserves (Oregon Master Gardener) and via social media on Facebook (Menlo Park, CA), Twitter (San Francisco, CA), and Instagram (Menlo Park, CA) targeting Oregon gardeners. These methods were used to reach as many gardeners as possible, particularly those who reside in the northwestern United States. The aesthetic preferences survey was open to responses between 10 July 2018 and 7 Jan. 2019. The ecological benefits survey was open to responses between 20 May and 25 Sept. 2019.

Analytical methods. We performed all statistical analysis using RStudio (RStudio, Boston, MA) and the statistical software $\mathrm{R}$ (version 3.5.1; R Core Team, Vienna, Austria). Across both surveys, the Likert responses to the "likelihood of planting" questions largely mirrored the responses to the "attractiveness" questions. Therefore, we only reported the Likert results for "likelihood of planting" questions here because this question is more pertinent to indicating potential adoption. We report the qualitative comments associated with both sets of questions.

Survey ONE: Aesthetic PREFERENCES. To determine whether there was a difference in "likelihood of planting" scores among native plant species, we performed an analysis of variance (ANOVA). Although Likert data are ordinal, not continuous, many statisticians believe it is acceptable to use parametric tests if the scale is 5 points or more points (Harpe, 2015) and the sample size is larger than 15 (Mircioiu and Atkinson, 2017). Our sample size was sufficiently large and consisted of 5 points; therefore, we performed a parametric type II partial sum of squares ANOVA using the "Anova" function in the "car" package (Fox and Weisberg, 2019). We did not perform post hoc comparisons among the 23 native plant species during this study because adjusting the probability values for 253 pairwise comparisons would result in extremely low statistical power. Instead, we used graphical displays to visually assess which plants were most attractive to gardeners using the "ggplot2" package (Wickham, 2016). The first graphical display was a bar graph of the mean aesthetics Likert scores for each plant species (Fig. 1). Our second graphical display was a diverging stacked bar chart of the Likert scores, which made it easier to visualize not only mean responses but also the distribution of the positive and negative ratings of native plant species (Fig. 2).

Additionally, we were interested in differences in the responses of native plant gardeners and non-native plant gardeners. We used a Welch's $t$ test (0.05 alpha level) to examine differences in mean responses between these two demographic groups. All $t$ tests in this study were performed using the "t.test" function in the R Base Package.

Survey two: Ecological BENEFITS. We used a paired $t$ test to evaluate whether the "likelihood of planting" scores were significantly different for all gardeners before and after the information related to the bees 


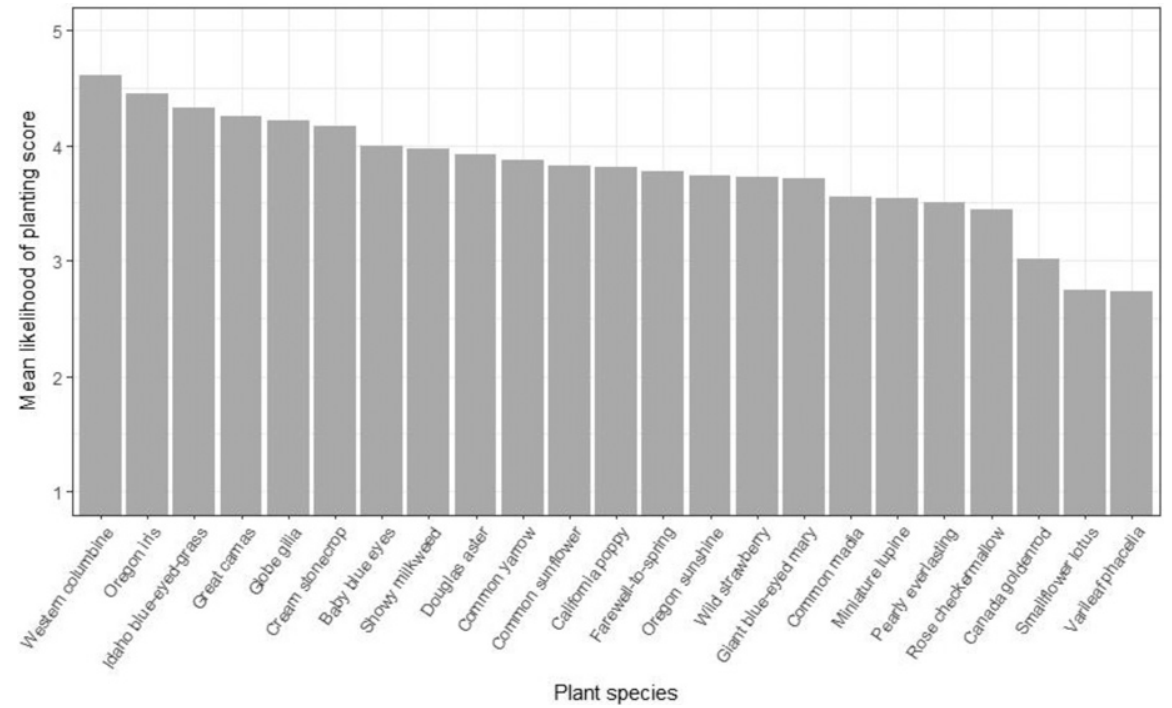

Fig. 1. Mean score (5-point Likert scale) of the likelihood respondents would garden with each of 23 plant species native to the Pacific Northwest United States, as ranked by respondents during an online survey (aesthetic preferences) investigating the appeal of these species to home gardeners. A Likert score of 1 represents the least attractive and a Likert score of 5 represents the most attractive. associated with each native plant was shared with participants. This allowed us to determine whether gardeners change their opinions after learning the ecological benefits of plant species. Again, with a large sample size, $t$ tests are robust for non-normal Likert data. We again used Welch's $t$ tests (0.05 alpha level) to determine if there was a statistically significant difference in the mean "likelihood of planting" responses of native plant gardeners and non-native plant gardeners before and after learning about the benefits to pollinators that these plants provide.

Finally, we calculated the differences between the before and after Likert scores for "likelihood of planting." We used Welch's $t$ tests $(0.05$ alpha level) to compare the mean score changes of native plant gardeners relative to those of nonnative plant gardeners to detect whether the mag-

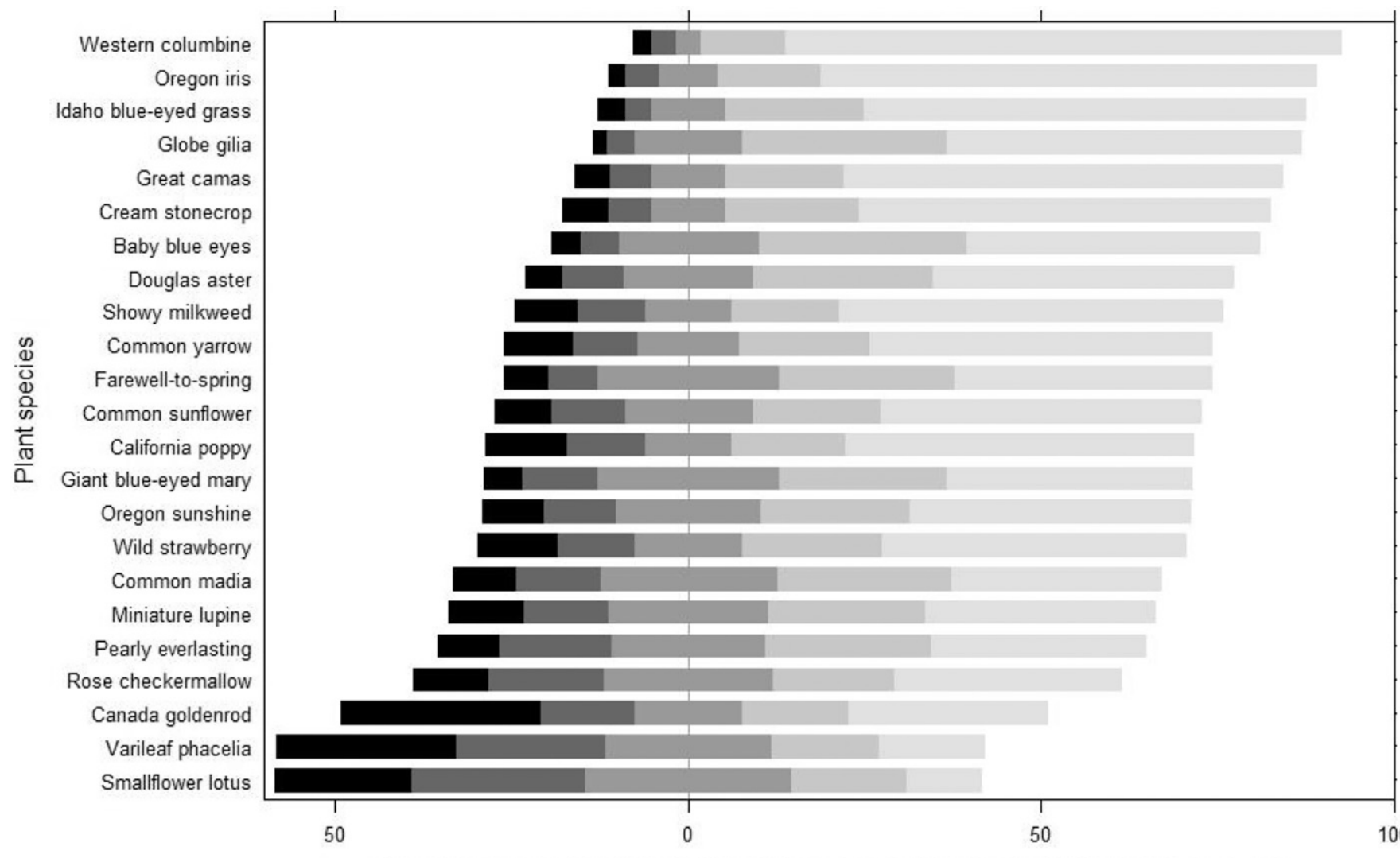

Proportion of 'likelihood of planting' responses falling into each of five Likert scores (\%)

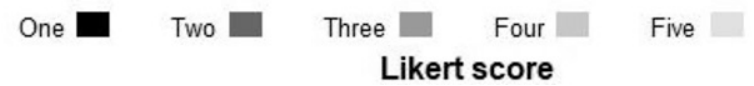

Fig. 2. Percentage of responses to the question "how likely would you be to plant this flower?" using five Likert scores of an online survey (aesthetic preferences) investigating the appeal of plant species native to the Pacific Northwest United States to home gardeners. A Likert score of 1 represents the least attractive and a Likert score of 5 represents the most attractive. 
Table 2. Definitions of the codes used to categorize the open-ended comments from two online surveys investigating the native plant preferences of home gardeners. The comments refer to the aesthetic appeal of the native plants to the respondents and the likelihood that the respondents would use these native plants in their home gardens. Codes help us understand patterns in gardeners' plant choices.

\begin{tabular}{|c|c|}
\hline Code & Definition \\
\hline \multicolumn{2}{|l|}{ Negative comments } \\
\hline Aesthetics & $\begin{array}{l}\text { Negative impression of aesthetics (e.g., color, size, foliage } \\
\text { shape, etc.) }\end{array}$ \\
\hline $\begin{array}{l}\text { Aggressiveness / } \\
\text { weediness }\end{array}$ & Concerns regarding aggressive growth or self-seeding \\
\hline Yard habitat & Gardener yard habitat is not appropriate for the plant \\
\hline Pest concerns & $\begin{array}{l}\text { Concern that a species will attract pests [i.e., pest insects, } \\
\text { deer (Cervidae), voles (Microtus sp.)] }\end{array}$ \\
\hline $\begin{array}{l}\text { Establishment/ } \\
\text { growth }\end{array}$ & $\begin{array}{l}\text { Pertaining to plant establishment/growth (i.e., slow, difficult } \\
\text { to establish) }\end{array}$ \\
\hline Availability & Unlikely to use because of low availability \\
\hline No space & Comment reflects a lack of space in which to grow this plant \\
\hline Allergies & Comment reflects concerns about allergies \\
\hline Phenology & Grows or blooms at a disagreeable time \\
\hline Not native & Gardeners claimed that the plant is not native to their region \\
\hline Poisonous & $\begin{array}{l}\text { Concern about plant toxicity [e.g., showy milkweed } \\
\text { (Asclepias speciosa)] }\end{array}$ \\
\hline Cross-pollination & $\begin{array}{l}\text { Concern regarding plants cross-pollinating with other plants } \\
\text { in/near garden }\end{array}$ \\
\hline General & General negative impression \\
\hline Cultural needs & Comments relating to concerns over cultural care practices needed \\
\hline Smell & Disagreeable smell \\
\hline \multicolumn{2}{|l|}{ Positive comments } \\
\hline Already have & Gardeners indicated they already garden with this plant \\
\hline Aesthetics & $\begin{array}{l}\text { Positive impression of aesthetics (e.g., color, size, foliage } \\
\text { shape, etc.) }\end{array}$ \\
\hline Ecology & $\begin{array}{l}\text { Positive impression of the plant's ecological benefits (i.e., } \\
\text { attracting wildlife, drought tolerance) }\end{array}$ \\
\hline Edible/medicinal & $\begin{array}{l}\text { Positive views of the plant's use for food or medicinal } \\
\text { purposes }\end{array}$ \\
\hline Ease of care & $\begin{array}{l}\text { Easy to care for (i.e., easy propagation, low water needs, } \\
\text { hardiness) }\end{array}$ \\
\hline Pest resistance & $\begin{array}{l}\text { Positive impression of the plant's resistance to pests (insect } \\
\text { pests, deer) }\end{array}$ \\
\hline Phenology & Grows or blooms at an agreeable time \\
\hline General & General positive impression \\
\hline Smell & Agreeable smell \\
\hline \multicolumn{2}{|l|}{ Neutral comments } \\
\hline $\begin{array}{l}\text { Need more } \\
\text { information }\end{array}$ & Gardeners stated the need for more information to decide \\
\hline I would if... & $\begin{array}{l}\text { Gardeners stated they would use this plant if certain } \\
\text { conditions were met }\end{array}$ \\
\hline $\begin{array}{l}\text { Unfamiliar with } \\
\text { plant }\end{array}$ & Gardeners are not familiar with this plant \\
\hline General & Neutral general impression \\
\hline
\end{tabular}

nitude of change was influenced by the short messages about pollinator-plant associations.

Survey comments. Both surveys generated qualitative results via open-ended response boxes that allowed respondents to reply with freeform comments related to each native plant species. To analyze these qualitative data, we coded themes found in open responses for each survey. Themes included the range of recorded responses and allowed us to aggregate responses in a manner that enabled us to assess potential patterns. These themes included aesthetics, ease of care, pest concerns, ecology, and aggressiveness (Table 2). In addition, each text response was classified as positive, negative, or neutral in reference to a theme. For example, the response "would not plant this, deer eat it" would be categorized as negative and pests. The response "I like purple flowers" would be categorized as positive and aesthetics.

After scoring the qualitative responses according to theme and connotation (e.g., positive or negative), we counted the number of comments with each code to determine the most positive and negative factors influencing respondents' impressions of native plant species. Responses with multiple themes were assigned to each code that was appropriate.

\section{Results}

Demographics. A total of 482 people fully or partially completed the aesthetic preferences survey. Of these, $64 \%$ considered themselves native plant gardeners, 33\% did not, and 3\% did answer the question related to whether they considered themselves to be a native plant gardener (Table 3 ).

A total of 334 people completed the ecological benefits survey. Of these, $44 \%$ considered themselves native plant gardeners, $22 \%$ did not, and $34 \%$ did not answer the native plant gardener question. Only $11 \%$ of respondents stated that they had completed the previous aesthetic preferences survey (Table 3).

Survey one: Aesthetic PrefeRENCES. The first survey asked gardeners to rank the attractiveness and the likelihood they would plant each of the 23 native plant species. Gardener rankings of the likelihood they would use each native plant differed significantly (at the 0.05 level $)$ among flower species $(P<$ $0.001)$. Although there was variance in gardeners' "likelihood of planting" (Fig. 1), visual inspection of the data showed that the difference between most native plant species was fairly small. The overall difference between the species with the highest score, western columbine [Aquilegia formosa (mean Likert score $=4.61)]$ and the lowest score, varileaf phacelia (mean Likert score $=2.73$ ) is moderate, differing by $41 \%$ on a 5 -point Likert scale. Only four native plant species had "likelihood" scoresless than 3.5 [rose checkermallow, canada goldenrod, smallflower lotus (Acmispon parviflorus), and varileaf phacelia]. Six of the flowers had a mean 
Table 3. Distribution of respondents who participated in two online surveys [aesthetic preferences $(\mathrm{N}=482)$ and ecological benefits $(\mathrm{N}=334)$ ] investigating the native plant preferences of home gardeners who identify as native plant gardeners. The second column displays the percentage of gardeners who participated in both the first survey and the second survey.

\begin{tabular}{|c|c|c|}
\hline Responses & $\begin{array}{c}\text { Respondents who were } \\
\text { native plant gardeners (\%) }\end{array}$ & $\begin{array}{c}\text { Respondents who participated } \\
\text { in the aesthetics preferences } \\
\text { survey }(\%)\end{array}$ \\
\hline & \multicolumn{2}{|c|}{ Aesthetic preferences survey } \\
\hline Yes & 63.7 & - \\
\hline No & 33.3 & - \\
\hline \multirow[t]{2}{*}{ No response } & 3.0 & - \\
\hline & \multicolumn{2}{|c|}{ Ecological benefits survey } \\
\hline Yes & 44.0 & 11.0 \\
\hline No & 22.2 & 51.2 \\
\hline No response & 33.8 & 37.8 \\
\hline
\end{tabular}

"likelihood" score of $\geq 4.0$ using the 5 -point Likert scale. These were western columbine (4.61), oregon iris [Iris tenax $(4.45)]$, idaho blue-eyed grass [Sisyrinchium idaboense (4.33)], great camas [Camassia leichtlinii (4.25)], globe gilia (4.56), and cream stonecrop [Sedum oregonense (4.15)]. Another six species had scores between 3.8 and 4.0: baby blue eyes [Nemophila menziesii (3.99)], showy milkweed [Asclepias speciosa (3.97)], douglas aster (3.92), common yarrow (3.87), common sunflower [ $\mathrm{Hel}$ ianthus annus (3.83)], and california poppy (3.81). There were no obvious groupings of plants that were "more likely" or "less likely" to be planted based on visual inspection of the mean Likert plots (Fig. 1).

Although most plants were relatively appealing to gardeners, visual inspection of the diverging stacked bar chart revealed no obvious groupings of plants that were more likely to be planted or that gardeners were unlikely to plant (Likert scores of 1 or 2 ), other than a noticeable increase in lower scores for the two plants with the lowest scores, smallflower lotus and varileaf phacelia (Fig. $2)$. Visually, canada goldenrod appeared to be polarizing, with fewer scores of 2,3 , and 4 than similarly ranking plants, and more scores of 1 and 5. Of those who participated in our survey, native plant gardeners $(\mathrm{N}$ = 307) were significantly more likely to be willing to plant the species than non-native plant gardeners $(\mathrm{N}=161)$ $(P<0.001)$.

Coded comments. There were 1643 individual comments in the aesthetic preferences survey across both the "attractiveness" and "likelihood" questions. Of these, 818 were coded as positive, 587 were coded negative, and
238 were coded neutral (Table 4 ). Regarding the negative comments, the two most common responses were negative impressions of the flowers' aesthetics $(\mathrm{N}=184)$ and concerns about the aggressiveness of plant growth $(\mathrm{N}=121)$. The theme of the most comments was "already have" (meaning the gardener indicated that they currently have this plant species in their garden currently or have gardened with it in the past) $(\mathrm{N}=627)$, whereas positive impressions of aesthetics $(\mathrm{N}=$ 107) and beneficial ecological traits $(\mathrm{N}=52)$ were the most common reasons given for positive impressions. In the neutral category, needing more information about a plant was the most common response $(\mathrm{N}=172)$, followed by "I would if ..." $(\mathrm{N}=38)$, which represented gardeners who liked the plants but expressed reasons why they would not use them.

Farewell-to-spring, showy milkweed, and california poppy were the species that received the most overall comments. Showy milkweed, california poppy, and western columbine had the most positive comments, whereas canada goldenrod, farewell-to-spring, and showy milkweed had the most negative comments (Fig. 3A).

Because so many gardeners stated that they had currently or previously gardened with any of these native plants, we counted the number of "already have" comments each received (Table 5). Common yarrow, western columbine, great camas, california poppy, and oregon iris all had more than 50 gardeners' comments,

Table 4. Number of respondent comments for each topic from a survey of 23 flowering plants native to the northwestern United States with the potential for use in home gardens. These comments were open-ended and referred to native plants' aesthetic appeal and likelihood that respondents would plant these species in their own garden $(\mathrm{N}=482)$.

\begin{tabular}{lclrr}
\hline Negative & Responses (no.) & Positive & Responses (no.) & Neutral \\
\hline Aesthetics & 184 & Already have & 627 & Need more information \\
Aggressiveness & 121 & Aesthetics & 107 & I would if... \\
Yard habitat issue & 57 & Ecology & 52 & Unfamiliar with plant \\
Establishment/growth & 48 & Ease of care & 13 & General \\
Availability & 44 & Edible/medicinal & 8 & Phenology \\
Pest concerns & 30 & Phenology & 6 & \\
No space & 27 & Pest resistance & 3 & \\
Allergies & 23 & General & 2 & \\
Phenology & 23 & & & \\
Not native & 10 & & & \\
Poisonous & 7 & & & \\
Cross pollination & 4 & & & \\
General & 2 & & & \\
Cultural needs & 7 & & & \\
\hline
\end{tabular}




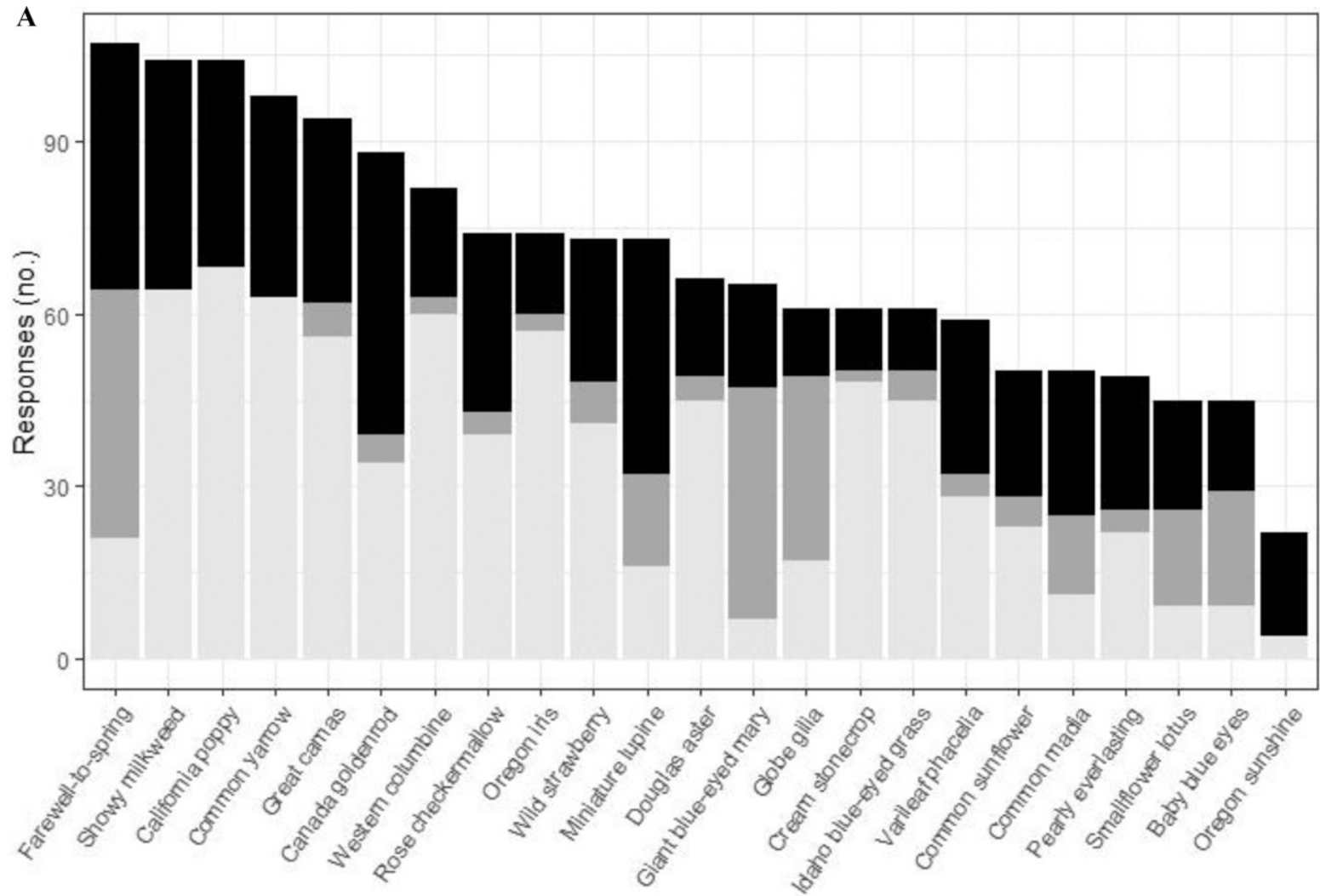

Response

Negative Neutral

Positive

\section{Plant species}

B

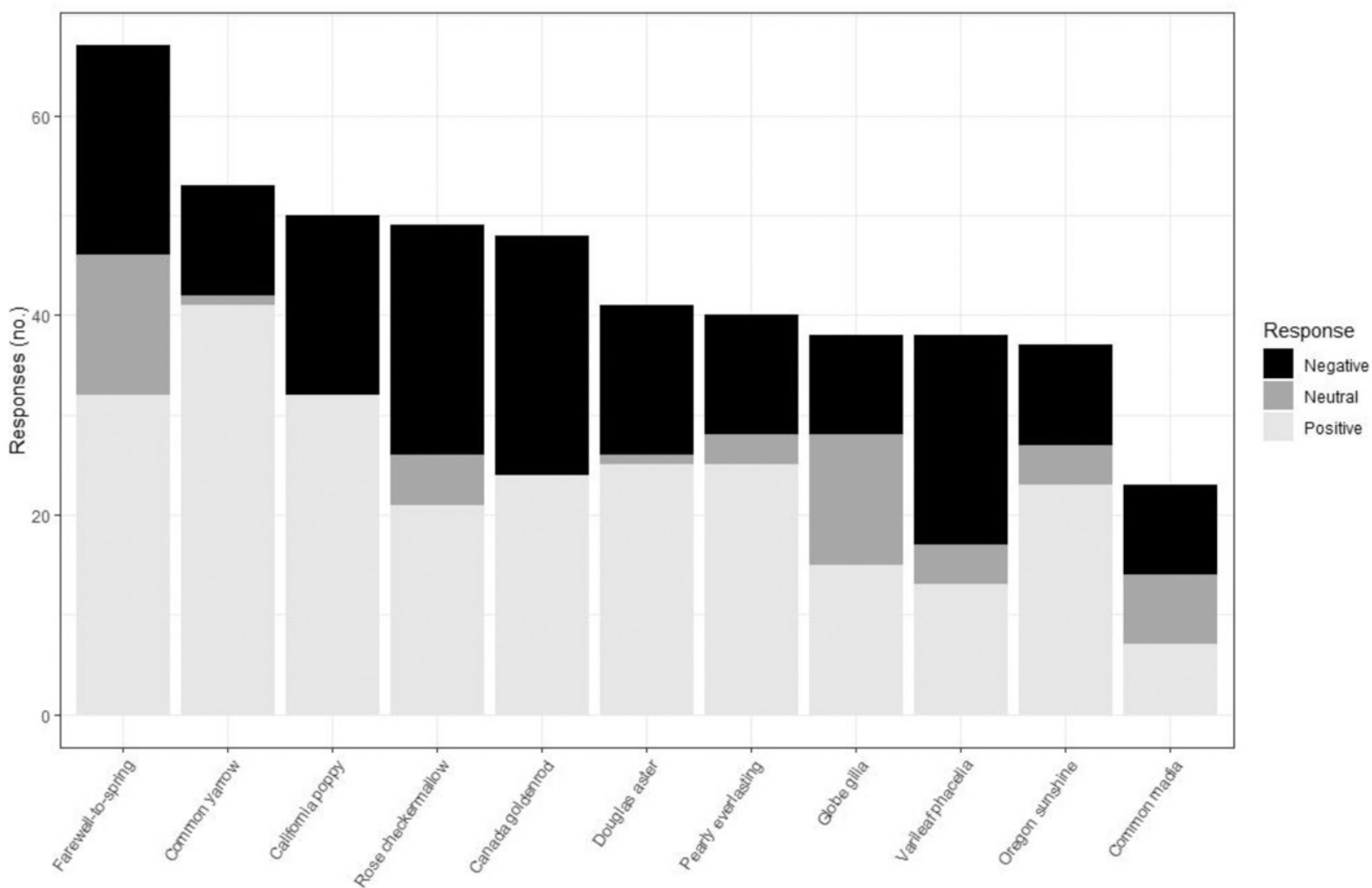

Plant species

Fig. 3. (A) Number of negative, positive, and neutral open-ended comments during an online survey (aesthetic preferences) investigating the appeal of 23 plant species native to the Pacific Northwest United States to home gardeners. (B) Number of negative, positive, and neutral gardener open-ended comments during a second online survey (ecological benefits) investigating the role of ecology in the appeal of 11 plant species native to the Pacific Northwest United States to home gardeners. 
Table 5. Number of comments from respondents indicating that they had currently or previously gardened with the native plant species listed on the survey of 23 flowering plants native to the northwestern United States with the potential for use in home gardens $(\mathrm{N}=482)$.

\begin{tabular}{lc}
\hline Plant species & Responses (no.) \\
\hline Common yarrow & 59 \\
Western columbine & 57 \\
Great camas & 52 \\
California poppy & 50 \\
Oregon iris & 50 \\
Showy milkweed & 43 \\
Idaho blue-eyed grass & 40 \\
Douglas aster & 38 \\
Cream stonecrop & 37 \\
Rose checkermallow & 33 \\
Wild strawberry & 32 \\
Oregon sunshine & 26 \\
Canada goldenrod & 24 \\
Common sunflower & 20 \\
Farewell-to-spring & 16 \\
Pearly everlasting & 14 \\
Globe gilia & 9 \\
Miniature lupine & 8 \\
Varileaf phacelia & 8 \\
Common madia & 5 \\
Giant blue-eyed mary & 3 \\
Baby blue eyes & 3 \\
Smallflower lotus & 0 \\
\hline
\end{tabular}

unprompted, indicating that they already used these species.

Survey tWo: ECOlOGICAL BENEFITS. After receiving information about the ecological attributes of study plants, gardeners stated that they would be significantly more likely to plant them overall $[P<0.001$ (Fig. 4)]. Access to information about the bees associated with each native plant increased the overall number of native plants with "likelihood of planting" Likert scores $\geq 4$ from three plants to eight plants (Fig. 4). Varileaf phacelia had the largest jump, with an increase in mean scores of $>1.0$ using the Likert scale.

Although the absolute Likert scores increased across all plants included in this second survey (Fig. 4), it is interesting to note that visual inspection of the relative positioning of native plants to each other revealed only minor reshuffling of each plant's rank. Plants that were of a lower rank before the ecological information was shared maintained a relatively low rank after gardeners learned more about the ecological attributes of the plant.

COMPARISON OF NATIVE PLANT GARDENERS TO OTHER GARDENERS. Respondents who identified as native plant gardeners $(\mathrm{N}=147)$ had significantly higher likelihood of planting Likert scores for all study plants compared with those who did not identify as native plant gardeners $(\mathrm{N}=74)$. This was the case for scores before gardeners received the information about bees associated with each plant $(P<$ $0.001)$ as well as after receiving this information $(P<0.001)$.

Compared with non-native plant gardeners, self-identified native plant gardeners did not exhibit a significantly different change in how likely they would be to plant these species after learning about their bee visitors $(P=$ 0.085 ).

Survey COMments. There were 485 individual comments in the ecological benefits survey across the "attractiveness" and "likelihood of planting" questions. Of these, 254 were coded as positive, 175 were coded as negative, and 56 were coded as neutral (Table 6 ). As in the first survey, the two most common negative responses were related to a native plant's aesthetics $(\mathrm{N}=57)$ and concerns about the aggressiveness of plant growth $(\mathrm{N}=34)$. Again, the code "already have" $(\mathrm{N}=195)$ was the most common positive theme, whereas positive impressions of aesthetics $(\mathrm{N}=27)$

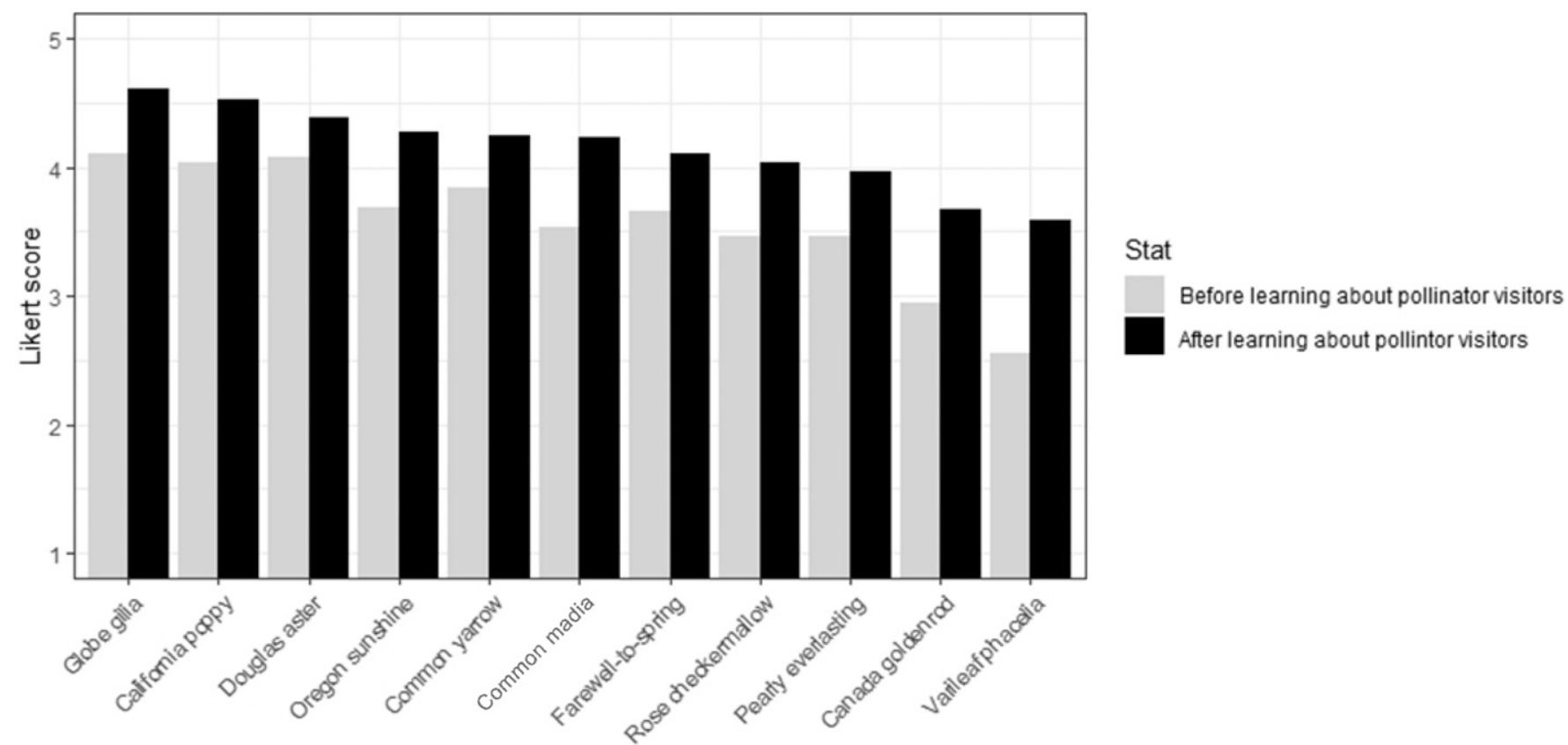

Plant species

Fig. 4. Mean score (5-point Likert scale) of the likelihood that respondents would garden with each of 11 plant species native to the Pacific Northwest United States before being provided with information about the pollinators that visit these plants displayed next to the mean "likelihood of planting" score by native plant species after learning about these plants' pollinator visitors. 
Table 6. Number of respondent comments for each topic from a survey of 11 flowering plants native to the northwestern United States known to be attractive to pollinators. These comments were open-ended and referred to native plants' aesthetic appeal and the likelihood that respondents would plant these species in their own garden $(\mathrm{N}=334)$.

\begin{tabular}{lclrr}
\hline Negative & Responses (no.) & Positive & Responses (no.) & Neutral \\
\hline Aesthetics & 57 & Already have & 195 & Need more information \\
Aggressiveness & 34 & Aesthetics & 27 & I would if... \\
Yard habitat issue & 24 & Ecology & 20 & Unfamiliar with plant \\
Availability & 19 & Ease of care & 4 & \\
Establishment/growth & 11 & Phenology & 4 & \\
No space & 10 & Edible/medicinal & 3 & \\
Allergies & 7 & General & 1 & \\
Phenology & 5 & & & \\
Not native & 5 & & & \\
Pest concerns & 2 & & & \\
Smell & 1 & & & \\
\hline
\end{tabular}

and beneficial ecological traits $(\mathrm{N}=20)$ were the most common reasons given for positive impressions. In the neutral category, needing more information about a native plant was the most common response $(\mathrm{N}=41)$, followed by "I would if ..." $(\mathrm{N}=13)$ (representing gardeners who liked the plants but expressed reasons they would not use them).

Farewell-to-spring again received the most comments overall, followed by common yarrow and california poppy. Common yarrow and california poppy received the most positive comments, whereas canada goldenrod and rose checkermallow received the most negative comments (Fig. 3B).

\section{Discussion}

Ultimately, we were interested in identifying native plants that gardeners would be willing to incorporate in ornamental garden settings on their properties. This information can be shared with gardeners to suggest specific native plants that both support pollinators and work well in residential landscapes. These recommendations can also help growers and sellers of native plants to target species that fit gardeners' aesthetic and ecological preferences.

Our results suggest that native plants can have high baseline acceptance by home gardeners, thus representing a potentially profitable market for nursery growers. However, not all native plants are likely to be equally embraced by the consumer market. We found significant differences in how likely gardeners would be to use our 23 study plants. Based on the results of the aesthetic preferences survey, the plants that showed the most promise for the retail nursery market were western columbine, oregon iris, idaho blue-eyed-grass, great camas, globe gilia, and cream stonecrop. These all had scores of $\geq 4.0$ using the 5 -point Likert scale. If we included results from the second survey, then california poppy, oregon sunshine, $\mathrm{co}^{-}$ mmon yarrow, common madia, farewell-to-spring, douglas aster, and rose checkermallow also scored $\geq 4.0$ for "likelihood of planting" after gardeners knew the attractiveness of these plants to bees.

It is notable that in these surveys, gardeners indicated acceptance for flowers that are not known for, and have not been bred for, their aesthetic beauty. Previous research has found that half of the surveyed gardeners said that attracting pollinators was a reason why they use pollinator-friendly plants (Campbell et al., 2017). This suggests that focusing marketing on both the ecological and aesthetic values of native plants might be advantageous to gain attention from the subset of gardeners who find them pretty, as well as those that are interested in promoting pollinator habitats.

The ecological benefits survey suggested that sharing a small amount of information about the benefits provided by bee-friendly plants can significantly increase how likely gardeners would be to use these plants. In this second survey, only 3 of the 11 plants included in the survey initially had mean "likelihood of planting" Likert scores more than 4.0. After learning about the bees associated with each native plant species, eight plants had mean scores more than 4.0. Notably, gardeners stated that they would be more likely to use all 11 native plants included in the second survey after being exposed to brief messages about the bees associated with each plant.

The increases we observed in these scores suggested that a significant subset of gardeners consider ecological traits a component of a flower's appeal, and that a minimal amount of education can significantly sway gardeners' opinions of native plants. Based on these results, nurseries and garden stores may be able to increase the palette of native plants that gardeners find attractive and suitable for planting by sharing brief messages about the ecological benefits these plants provide. Previous research has shown that labels result in consumers paying a premium for native plants (Yue et al., 2011, 2012); therefore, labeling might benefit growers by increasing the quantity of native plants sold and their individual prices.

Our findings that the stated likelihood that gardeners will use native plants can be increased by small amounts of education are encouraging for efforts to increase ecological function in urban and suburban landscapes and highlight the importance of outreach and education to the success of these efforts. Even if people are willing to take ecology into consideration, they will not plant ecologically friendly flowers if they are unaware of the benefits of these plants. In addition, gardeners' perceptions of "pollinatorfriendly" flower traits vary and are frequently incorrect (Khachatryan and Rihn, 2018). Although some gardeners select traits like pollen production and nectar production (generally good for pollinators), others gravitate toward bright flowers and brightly colored foliage, which are traits that are often not 
beneficial to pollinators (Khachatryan and Rihn, 2018). Existing ideas and knowledge frequently bias gardeners' impressions of what a pollinator-friendly plant is (Campbell et al., 2017; Wollaeger et al., 2015).

Not surprisingly, the respondents who identified as native plant gardeners were significantly more likely to find native plants attractive, both before and after learning about the pollinator attractiveness of these plants. It stands to reason that gardeners who are already aware of these species and enjoy using them would be more appreciative of their aesthetics.

Our findings are encouraging, especially because there were various reasons why gardeners may or may not include a plant in their garden. Although we did not share the "attractiveness" scores from our survey (because they tracked the same patterns observed for the "likelihood of planting" scores), the mean "attractiveness" Likert scores were slightly, but consistently, higher than the mean "likelihood" scores. This score gap is not surprising because gardeners consider more factors than just aesthetics when deciding what to plant.

The coded comments from the aesthetic preferences survey provide insight regarding some of the factors and concerns that may drive gardeners' native plant choices and the gap between how attractive gardeners find plants and their willingness to plant them. These survey comments revealed that, second only to aesthetics, the aggressiveness or weediness of native plants was a major concern to gardeners. Although these comments appeared less often, concerns about successful plant establishment, not having an appropriate yard, and potential lack of availability were mentioned by gardeners.

Although the survey respondents were presumably highly educated about garden topics (many were Master Gardeners, $\mathrm{N}=\mathbf{5 2 3}$ across both surveys), a substantial number of comments referred to needing more information or being unfamiliar with the plants. Additionally, gardeners had misconceptions about some of these plants, which may have reduced their scores. For example, canada goldenrod received multiple comments about it causing allergies, and it is likely that gardeners were confusing this species with allergenic ragweeds (Ambrosia sp.). These comments further reinforce the need for outreach and education on behalf of native plants.

Moving forward, these results can inform the sale of native plant materials on the retail market. There is growing interest in using native plants in ornamental landscapes, but most gardens are comprised of exotic plants. For example, Smith et al. (2006) found that garden flora in Sheffield, England, comprised 70\% exotic plants. Contributing to this is a lack of availability because many larger "box" garden stores have few native species available for sale (Avolio et al., 2018; Wilde et al., 2015). Additionally, native plant species may have traits deemed to be undesirable in gardens, as reflected in our survey comments.

Native plants that are not traditionally aesthetically pleasing may still have a place in the modern ornamental landscape. Cubino et al. (2020) surveyed homeowner vegetation and management choices for 145 yards across the United States and found that landscape priorities were largely separated into four categories: natural, neat, showy, and low-cost. This revealed that gardeners do have different priorities, and our gardener comments tracked these results. Appropriate native plants may be uniquely able to cross these categories with broad appeal. They can be marketed for use in native or "natural" landscaping, can be drought-tolerant and need few soil amendments ("lowcost" gardens), and many species are attractive (for use in "showy" gardens).

To increase the promise of the native plant market, nurseries should provide increased availability of plants that fit the desired criteria, such as aesthetics, growth habit, and size. To do so effectively, native plants marketed for sale by nurseries and garden stores may need to clear a baseline appeal threshold to home gardeners and should be coupled with messages that extol the nonaesthetic benefits of particular plants. Based on the results of our surveys and the results from our companion field study (A.G. Anderson and G.A. Langellotto, unpublished data), we suggest that globe gilia, california poppy, douglas aster, oregon sunshine, and common yarrow are good candidates for plants that have high aesthetic appeal and can also be marketed as bee-friendly plants.
Many respondents to the aesthetic preferences survey commented that they already used some of these native plants in their home gardens. Of the candidate native plants we recommend, common yarrow had 59 "already have" comments, and california poppy had 50 "already have" comments. This may suggest that these two species already have higher market availability. However, douglas aster $(\mathrm{N}=38)$, oregon sunshine $(\mathrm{N}=26)$, and globe gilia $(\mathrm{N}=$ 9) had substantially fewer of these comments. This further reinforces the idea that these plants have an opportunity for nurseries to consider propagating and marketing.

\section{Limitations}

It should be noted that potential biases existed during these surveys. Self-selection was present because of our recruitment methods (Bethlehem, 2010). Both surveys were distributed via e-mail listservs and social media channels to reach as many gardeners as possible at low cost. Therefore, we did not randomly select participants. Perhaps gardeners who participated were largely from certain demographics that may influence their views of native plants. Previous research has found that the adoption of ecologically friendly practices is influenced by social norms (Bamberg, 2003). Age, education, and location are associated with the adoption of environmentally friendly practices, but not gender or race (Dietz et al., 1998), and it may be that similar dynamics influenced this study.

Additionally, only gardeners who had access to the Internet and were able to read English could participate in our surveys. In general, those with Internet access often answer questions differently than those without (Bethlehem, 2010); therefore, these results were biased to the responses of a population with web access. Similarly, English-speaking gardeners encompass demographics with certain viewpoints and values that may differ from those of some non-Englishspeaking demographics.

The survey questions were not presented in a new random order to each respondent, which might have introduced bias or survey fatigue as confounding variables when interpreting the results. People may have become tired of responding by the end of the survey; therefore, they might have ranked the plants at the end 
consistently higher or lower. However, a visual display of the mean Likert scores displayed in the order of the survey did not indicate a detectable pattern (data not shown). To further verify this, we performed a $t$ test for the mean scores of the first half and second half of the survey and found no significant difference between the two (data not shown). However, placing the demographic section at the end of the second survey $(33.8 \%$ nonresponse rate for the question asking if they are native plant gardeners) instead of the beginning, as in our first survey $(3.0 \%$ nonresponse rate for the same question) was likely the cause of the differences in responses to these questions.

We could not calculate a response rate because it was impossible to know how many gardeners received the survey link. We could not reach causal conclusions because this is an observational study, and we could not extend inferences or generalizations from this sample to any larger populations because these surveys were voluntary response samples, not random samples. However, we could observe the opinions and behaviors of our respondents. Our considerably large sample size ( $\mathrm{N}=816$ across both surveys) allowed us to gain insight regarding the opinions of many gardeners as a general group.

\section{Conclusions}

Native plant gardening has increased in popularity. There needs to be a corresponding increase in the understanding of which plants provide specific ecological benefits, which are most attractive to gardeners, and the interaction between these two factors. Our study indicates that gardeners have high potential to include plants native to the northwestern United States in their yards. Furthermore, the results of our ecological benefits survey indicate that only a minimum amount of education significantly increases gardeners' positive impressions of native plants.

\section{Literature cited}

Avolio, M.L., D.E. Pataki, T.L. Trammell, and J. Endter-Wada. 2018. Biodiverse cities: The nursery industry, homeowners, and neighborhood differences drive urban tree composition. Ecol. Monogr. 88:259276, doi: 10.1002/ecm.1290.
Baldock, K.C., M.A. Goddard, D.M. Hicks, W.E. Kunin, N. Mitschunas, L.M. Osgathorpe, S.G. Potts, K.M. Robertson, A.V. Scott, G.N. Stone, and I.P. Vaughan. 2015. Where is the UK's pollinator biodiversity? The importance of urban areas for flowervisiting insects. Proc. Biol. Sci. 282:2014 2849, doi: 10.1098/rspb.2014.2849.

Bamberg, S. 2003. How does environmental concern influence specific environmentally related behaviors? A new answer to an old question. J. Environ. Psychol. 23:21-32, doi: 10.1016/S0272-4944(02)00078-6.

Bethlehem, J. 2010. Selection bias in web surveys. Intl. Stat. Rev. 78:161-188, doi: 10.1111/j.1751-5823.2010.00112.x.

Brzuszek, R.F. and R.L. Harkess. 2009. Green industry survey of native plant marketing in the southeastern United States. HortTechnology 19:168-172, doi: 10.21273/HORTSCI.19.1.168.

Burghardt, K.T., C.R. Philips, D.W. Tallamy, and K.J. Shropshire. 2010. Non-native plants reduce abundance, richness, and host specialization in lepidopteran communities. Ecosphere 1:1-22, doi: 10.1890/ ES10-00032.1.

Burghardt, K.T. and D.W. Tallamy. 2015. Not all non-natives are equally unequal: Reductions in herbivore $\beta$-diversity depend on phylogenetic similarity to native plant community. Ecol. Lett. 18: 1087-1098, doi: 10.1111/ele.12492.

Campbell, B., H. Khachatryan, and A. Rihn. 2017. Pollinator-friendly plants: Reasons for and barriers to purchase. HortTechnology 27:831-839, doi: 10.21273/ HORTTECH03829-17.

Cubino, J.P., J. Cavender-Bares, P.M. Groffman, M.L. Avolio, A.R. Bratt, S.J. Hall, K.L. Larson, S.B. Lerman, D.L. Narango, C. Neill, T.L. Trammell, M.M. Wheeler, and S.E. Hobbie. 2020. Taxonomic, phylogenetic, and functional composition and homogenization of residential yard vegetation with contrasting management. Landsc. Urban Plan. 202:103877, doi: 10.1016/j.landurbplan.2020.103877.

Dietz, T., P.C. Stern, and G.A. Guagnano. 1998. Social structural and social psychological bases of environmental concern. Environ. Behav. 30:450-471, doi: 10.1177/ 001391659803000402 .

Fox, J. and S. Weisberg. 2019. An $\{R\}$ companion to applied regression. 3rd ed. Sage, Thousand Oaks, CA.

Fukase, J. and A.M. Simons. 2016. Increased pollinator activity in urban gardens with more native flora. Appl. Ecol. Environ. Res. 14:297-310, doi: 10.15666/ aeer/1401_297310.
Hallmann, C.A., M. Sorg, E. Jongejans, H. Siepel, N. Hofland, H. Schwan, W. Senmans, A. Müller, H. Sumser, T. Hörren, D. Goulson, and H. de Kroon. 2017. More than 75 percent decline over 27 years in total flying insect biomass in protected areas. PLoS One 12:e0185809, doi: 10.1371/journal.pone.0185809.

Harpe, S.E. 2015. How to analyze Likert and other rating scale data. Curr. Pharm. Teach. Learn. 7:836-850, doi: 10.1016/ j.cptl.2015.08.001.

Hostetler, N.E. and M.E. McIntyre. 2001. Effects of urban land use on pollinator (Hymenoptera: Apoidea) communities in a desert metropolis. Basic Appl. Ecol. 2:209-218, doi: 10.1078/14391791-00051.

Howard, C. 2018. ASLA survey: Demand high for sustainable residential landscapes. 12 Oct. 2020. <https://www.gardencenter mag.com/article/asla-demand-sustainableresidential-landscapes $/>$.

Kauth, P.J. and H.E. Pérez. 2011. Industry survey of the native wildflower market in Florida. HortTechnology 21:779-788, doi: 10.21273/HORTTECH.21.6.779.

Khachatryan, H. and A.L. Rihn. 2018. Defining U.S. consumers' (mis)perceptions of pollinator friendly labels: An exploratory study. Intl. Food Agribus. Mgt. Rev. 21:365-378, doi: 10.22004/ag.econ.269672.

Loram, A., K. Thompson, P.H. Warren, and K.J. Gaston. 2008. Urban domestic gardens (XII): The richness and composition of the flora in five UK cities. J. Veg. Sci. 19: 321-330, doi: 10.3170/2008-8-18373.

Matteson, K.C. and G.A. Langellotto. 2011. Small scale additions of native plants fail to increase beneficial insect richness in urban gardens. Insect Conserv. Divers. 4:89-98, doi: 10.1111/j.1752-4598.2010.00103.x.

Mircioiu, C. and J. Atkinson. 2017. A comparison of parametric and non-parametric methods applied to a Likert scale. Pharmacy 5:26, doi: 10.3390/pharmacy 5020026 .

Narango, D.L., D.W. Tallamy, and P.P. Marra. 2017. Native plants improve breeding and foraging habitat for an insectivorous bird. Biol. Conserv. 213:42-50, doi: 10.1016/j.biocon.2017.06.029.

Norcini, J.F. 2007. Native plants: An overview. 2016. Univ. Florida, Inst. Food Agric. Sci. Ext. Publ. ENH1045. 12 Oct. 2020. <https://edis.ifas.ufl.edu/ep297>.

Salisbury, A., J. Armitage, H. Bostock, J. Perry, M. Tatchell, and K. Thompson. 2015. Editor's choice: Enhancing gardens as habitats for flower-visiting aerial insects (pollinators): Should we plant native or 
exotic species? J. Appl. Ecol. 52:1156-1164, doi: 10.1111/1365-2664.12499.

Sánchez-Bayo, F. and K.A. Wyckhuys. 2019. Worldwide decline of the entomofauna: A review of its drivers. Bio. Cons. 232:8-27, doi: 10.1016/j.biocon.2019. 01.020 .

Smith, R.M., K. Thompson, J.G. Hodgson, P.H. Warren, and K.J. Gaston. 2006. Urban domestic gardens (IX): Composition and richness of the vascular plant flora, and implications for native biodiversity. Biol. Conserv. 129:312-322, doi: 10.1016/ j.biocon.2005.10.045.

Uren, H.V., P.L. Dzidic, and B.J. Bishop. 2015. Exploring social and cultural norms to promote ecologically sensitive residential garden design. Landsc. Urban Plan. 137:76-84, doi: 10.1016/j.landurbplan. 2014.12.008.
U.S. Department of Agriculture. 2016. The PLANTS database. 10 Dec. 2016. $<$ http://plants.usda.gov $>$.

White, A., J.B. Fant, K. Havens, M. Skinner, and A.T. Kramer. 2018. Restoring species diversity: Assessing capacity in the U.S. native plant industry. Restor. Ecol. 26:605-611, doi: 10.1111/rec.12705.

Wickham, H. 2016. ggplot2: Elegant graphics for data analysis. Springer-Verlag, New York, NY.

Wilde, H.D., J.K.G. Kamal, and G. Colson. 2015. State of the science and challenges of breeding landscape plants with ecological function. Hort. Res. 2:14069, doi: 10.1038/hortres.2014.69.

Williams, N.M., D. Cariveau, R. Winfree, and C. Kremen. 2011. Bees in disturbed habitats use, but do not prefer, alien plants. Basic
Appl. Ecol. 12:332-341, doi: 10.1016/j. baae.2010.11.008.

Wollaeger, H.M., K.L. Getter, and B.K. Behe. 2015. Consumer preferences for traditional, neonicotinoid-free, bee-friendly, or biological control pest management practices on floriculture crops. HortScience 50:721732, doi: 10.21273/HORTSCI.50.5.721.

Yue, C., T.M. Hurley, and N.O. Anderson. 2011. Do native and invasive labels affect consumer willingness to pay for plants? Evidence from experimental auctions. Agr. Econ. 42:195-205, doi: 10.1111/j.15740862.2010.00510.x

Yue, C., T.M. Hurley, and N.O. Anderson. 2012. Heterogeneous consumer preferences for native and invasive plants: Evidence from experimental auctions. HortScience 47:1091-1095, doi: 10.21273/HORT SCI.47.8.1091. 


\section{Supplemental Material S1}

This survey was designed to ascertain the baseline aesthetic appeal of 23 different native Willamette Valley, Oregon, wildflowers to gardeners, as well as their willingness to include these species in their own home gardens.

Our study is investigating the relative attractiveness of Willamette Valley, Oregon, wildflowers to pollinators and natural enemies. We hope that pollinator-friendly plants will be used by home gardeners, thus providing habitat for these insects in urban and suburban landscapes. We are interested in your opinion on the ornamental value of these native plants that could be planted in western Oregon gardens.

\section{Demographic Questions}

1. Are you over 18 years old?
a. Yes
b. No

2. Are you currently a Master Gardener, or have you been a Master Gardener in the past?
a. Yes
b. No

3. How long have you been a gardener? Please answer to the nearest year, such as "10 years" or "1 year."

4. Would you consider yourself a "native plant gardener"?
a. Yes
b. No

5. Do you currently have native plants in your garden? If so, what kinds? Select all that apply.
a. Trees
b. Shrubs
c. Herbaceous annuals
d. Herbaceous perennials
e. Bulbs
f. Other

6. What barriers might prevent YOU from including more native plants in their garden? Select all that apply.
a. Cost
b. Availability
c. Aesthetics
d. Upkeep
e. Other

7. What barriers do you think might prevent OTHER GARDENERS from including more native plants in their garden? Select all that apply.
a. Cost
b. Availability
c. Aesthetics

$$
\begin{aligned}
& \text { d. Upkeep } \\
& \text { e. Other }
\end{aligned}
$$

\section{Plant Aesthetics and Willingness to Plant Questions}

Gardeners were shown photos of the following plants and asked to rank them on a scale of 1 (lowest) to 5 (highest), in terms of (a) each plant's attractiveness and (b) their willingness to include this plant in their garden. Gardeners were also offered the opportunity to provide additional comments about each plant, based upon the provided photo.

1. Clarkia amoena. Common name: Farewell-to-spring

2. Collinsia grandiflora. Common name: Giant blue-eyed mary

3. Gilia capitata. Common name: Blue headed gilia

4. Lupinus microcarpus. Common name: Miniature lupine

5. Madia elegans. Common name: Common madia

6. Nemophila menziesii. Common name: Baby blue eye

7. Eschscholzia californica. Common name: California poppy

8. Helianthus annuus. Common name: Common sunflower

9. Phacelia heterophylla. Common name: Varied-leaf phacelia

10. Acmispon parviflorus. Common name: Smallflower lotus

11. Achillea millefolium. Common name: Common yarrow

12. Anaphalis margaritacea. Common name: Pearly everlasting

13. Asclepias speciosa. Common name: Showy milkweed

14. Aquilegia Formosa. Common name: Western columbine

15. Symphyotrichum subspicatum, Common Name: Douglas' aster

16. Camassia leichtlinii. Common name: Great camas

17. Eriophyllum lanatum. Common name: Oregon sunshine

18. Fragaria vesca. Common name: Woodland strawberry

19. Iris tenax. Common name: Oregon iris

20. Sedum oregonense. Common name: cream stonecrop

21. Sidalcea asprella ssp. virgata. Common name: Rose checkermallow
22. Sisyrinchium idahoense. Common name: Idaho blue-eyed-grass

23. Solidago canadensis. Common name: Canada goldenrod

\section{Supplemental Material S2}

This survey was designed to assess how malleable gardener opinions of native plants are after being educated about the benefits they provide to pollinators. This survey consists of a subset of the most attractive pollinator plants from the 2017 and 2018 field seasons.

We are studying the relative attractiveness of Willamette Valley, Oregon, native wildflowers to insect pollinators and natural enemies. We are also interested in understanding the potential value of these plants to home gardeners and landscapers. Thus, we would like to know your opinion on the ornamental beauty of these plants. We would also like to know whether or not the ecological benefits provided by various plants might influence opinions related to these same plants.

\section{Demographic Questions}

1. Are you over 18 years old?

a. Yes

b. No

2. What area best represents where you garden?
a. Willamette Valley, Oregon
b. Another region within Oregon
c. Outside of Oregon
d. Outside of the United States

3. Did you participate in our previous survey on native plant aesthetics?
a. Yes
b. Unsure
c. No

4. Are you currently a Master Gardener, or have you been a Master Gardener in the past?
a. Yes
b. No

5. How long have you been a gardener? Please answer to the nearest year, such as "10 years" or "1 year."

6. Would you consider yourself a "native plant gardener"?
a. Yes
b. No

7. Do you currently have native plants in your garden? If so, what kinds? Select all that apply.
a. Trees
b. Shrubs
c. Herbaceous annuals
d. Herbaceous perennials 

e. Bulbs
f. Other

8. What barriers might prevent YOU from including more native plants in their garden? Select all that apply.
a. Cost
b. Availability
c. Aesthetics
d. Upkeep
e. Other

9. What barriers do you think might prevent OTHER GARDENERS from including more native plants in their garden? Select all that apply.
a. Cost
b. Availability
c. Aesthetics
d. Upkeep
e. Other

\section{Plant Aesthetics and Willingness to Plant Questions}

Gardeners were shown photos of a subset of ten plants from survey one that had

study and asked to rank them on Ckaakicofamoena. Common name: Farewell-to-spring

1 (lowest) to 5 (highest), in terms of (a) each plant's attractiveness and (b) their willingness to include this plant in their garden. Gardeners were also offered the opportunity to provide additional comments about each plant, based upon the provided photo.

For each plant, gardeners were then shown a photo of a bee visiting each flower accompanied by a fact from our first two years of field studies (e.g., "Phacelia heterophylla was the most attractive flower to bumble bees in both the first and second years of our study."). We then asked gardeners whether they viewed this flower as more attractive, and again asked them to rank on a scale of 1 (lowest) to 5 (highest), in terms of (a) each plant's attractiveness and (b) their willingness to include this plant in their garden after learning of the ecological benefit to pollinators it provides.

Opportunity to provide additional comments about each plant, based upon the provided photo.
2. Gilia capitata. Common name: Blue headed gilia

3. Madia elegans. Common name: Miniature lupine

4. Eschscholzia californica. Common name: California poppy

5. Phacelia heterophylla. Common name: Varied-leaf phacelia

6. Achillea millefolium. Common name: Common yarrow

7. Anaphalis margaritacea. Common name: Pearly everlasting

8. Symphyotrichum subspicatum. Common name: Douglas' aster

9. Eriophyllum lanatum. Common name: Oregon sunshine

10. Sidalcea asprella ssp. Virgata. Common name: Rose checkermallow

11. Solidago canadensis. Common name: Canada goldenrod 